\title{
Hafif/Orta Şiddette Alt veya Üst Ekstremite Direnç Egzersizlerinin Akciğer İşlevleri ve Yaşam Kalitesi Üzerine Etkisi ${ }^{*}$
}

\author{
Hacı Osman ÜNAL ${ }^{1,2}$, Funda COŞKUN ${ }^{1,3}$, Aslı GÖREK DÍLEKTAŞLI ${ }^{3}$, \\ Yusuf Emin GÖKALP ${ }^{1,4}$, Fadıl ÖZYENER
}

1

2

3

4

ÖZET

Çalısmamızda, hafif/orta siddette yapılan alt veya üst ekstremite direnç egzersizlerinin kronik solunum sistemi sorunları olan kișilerde akciğer işlevleri ve yaşam kalitesi üzerine etkisinin incelenmesi amaçlandı. 35-80 yaş arası 20 kronik akciğer hastası ve 15 sağlıklı birey çalışmaya gönüllü oldu. Bu 2 grup kendi içlerinde alt ve üst ekstremite direnç egzersizlerini yapmak üzere randomize olarak 2 alt gruba bölünerek toplam 4 grup olușturuldu. Egzersiz programı günde 2-3 kere, haftada 3 gün ev programı seklinde planlandı ve uygulamalı olarak katılımcılara gösterildi. Antrenmanın toplam süresi en az 2, en fazla 4 ay olmak üzere planlandı. Katılımcıların solunum fonksiyonları $\left(\mathrm{FEV}_{1}\right.$, FVC, $\mathrm{FEV}_{1} / \mathrm{FVC}, \mathrm{PEF}, \mathrm{MEF}_{75}, \mathrm{MEF}_{50}, \mathrm{MEF}_{25}$ ) spirometrik ölçümlerle, yașam kaliteleri ise St. George Solunum Anketi (SGRQ) ile antrenman öncesi ve 2-4 ay sonrası değerlendirildi. İstatistiksel anlamlılık düzeyi $p<0,05$ olarak kabul edilerek gruplar birbirleriyle ve kendi içlerinde karşılaştırıldı. Katılımcıların egzersiz programı öncesi ve sonrasında solunum fonksiyon testi (SFT) parametreleri karşılaştırıldığında anlamlı bir fark bulunamadı $(\mathrm{p}>0,05)$. Egzersiz programı sonrasında hasta grubun yașam kalitesi anket skorları anlamlı düzeyde azaldı $(\mathrm{p}<0,001)$. Sonuç olarak, kronik akciğer sorunu olan hastalarda hafif/orta şiddette alt veya üst ekstremite direnç egzersizlerinin de ev ortamında düzenli olarak yapılması halinde yaşam kalitesinde iyileşme sağlayabileceği görüldü. SFT parametrelerine bu iyileşmenin somut olarak yansıması için egzersiz şiddetinin ve egzersize devamlılı̆ın sağlanmasında daha yakın izleme ve planlamanın yararlı olabileceği düşünüldü.

Anahtar Kelimeler: Alt ekstremite egzersizleri. Üst ekstremite egzersizleri. Solunum işlevleri. Yaşam kalitesi.

The Effect of Mild/Moderate Lower or Upper Extremity Resistance Exercises on Pulmonary Functions and Quality of Life

\section{ABSTRACT}

In our study, we aimed to investigate the effects of lower or upper extremity resistance exercises on lung function and quality of life in people with chronic respiratory problems. Twenty chronic lung patients and 15 healthy subjects aged 35-80 were volunteered. In total 4 groups were formed by dividing these two groups randomly into 2 subgroups within themselves to perform lower and upper extremity resistance exercises. The home exercise program was 2-3 times a day, 3 days a week, and how to perform exercises were demonstrated to the

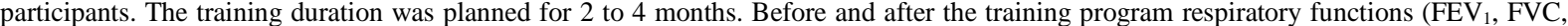
$\mathrm{FEV}_{1} / \mathrm{FVC}, \mathrm{PEF}, \mathrm{MEF}_{75}, \mathrm{MEF}_{50}, \mathrm{MEF}_{25}$ ) of the participants were evaluated by spirometric measurements and the quality of life was determined by St George's Respiratory Questionnaire (SGRQ). The statistical significance level was accepted as $p<0,05$. When the respiratory function test parameters of the participants were compared before and after the exercise program, no significant difference was found ( $>$ $0,05)$. After the exercise program, the quality of life questionnaire scores of the patient group decreased significantly $(p<0,001)$. As a result, it was seen that mild/moderate lower or upper extremity resistance exercises in patients with chronic lung problems could improve the quality of life if performed regularly in the home environment. Additionally, it was thought that in order to transform this quality improvement into the spirometric measurements, better planning of the intensity and closer monitoring of continuity of exercise could be useful.

Key Words: Lower extremity exercises. Upper extremity exercises. Respiratory functions. Quality of life.

Geliş Tarihi: 13 Şubat 2019

Kabul Tarihi: 16 Mayıs 2019

* 44. Ulusal Fizyoloji Kongresi'nde sözel bildiri olarak sunulmuştur (1-4 Kasım 2018, Antalya)

Dr. Fadıl ÖZYENER

Bursa Uludağ Üniversitesi Tıp Fakültesi,

Fizyoloji Anabilim Dalı, Bursa.

Tel.: 02242954013

E-posta: fozyener@uludag.edu.tr
Egzersiz yaparken ve sonrasında oluşabilen nefes darlığı, öksürük, göğüste sıkışma hissi gibi yakınmalar sağlık sorunu olmayan insanlarda da bazen gözlenebilir. Öte yandan benzer şikayetler gerek astım gerek kronik obstrüktif akciğer hastalığı (KOAH) tanısı almış uzun süreden beri akciğer sorunları olan kişilerde daha sık görülür ${ }^{1,2}$. KOAH, akciğer kapasitesinde azalma ve hava yolu direncinde artma ile karakterize, 
kronik ilerleyici bir akciğer hastalığıdır ${ }^{3}$. Hastalarda akciğerin iş yükü ve ventilasyonun litre cinsinden işi artar. Bu sebeple bireylerde solunum yetersizliği, efor dispnesi ve fiziksel kapasitede azalma görülür ${ }^{4}$.

Astım, yaygın görülen ve her yaş grubunu etkileyen, oluşumunda genetik faktörlerin yanı sıra çevresel faktörlerin de rol oynadığı bir hastalıktır ${ }^{2,5}$. Havayolları daralmasının yanı sıra, inflamasyon ve bronşlarda aşırı duyarlılık ile karakterizedir. İleri yaşlarda daha sık görülen ve sigara içimi ile çok yakından ilişkili olan KOAH'ta ise solunum yüzeyinin kaybı daha ön plandadır. Gerek astım gerek KOAH fizyopatolojisinde ortak nokta olarak, akciğerlerin vücuda zararlı veya yabancı partiküllere/gazlara karşı anormal inflamasyon cevabı geliştirdikleri bildirilir ${ }^{1,5-7}$. Akciğerlere lokalize veya sistemik olabilen inflamasyon ile havayollarının özellikle egzersiz sırasında ve/veya sonrasında gereken cevabı oluşturamaması yüzünden yukarda anılan yakınmalar bu kişilerde daha sıktır ${ }^{8,9}$.

Ulaşılan evreye bağlı olarak hastalık ilerledikçe söz konusu şikayetleri tetikleyebileceği korkusu ile hareketli olmaktan veya egzersiz yapmaktan kaçınma, bu kişilerde sık görülmektedir. Oysa hem hareketsizlik hem de hastalığın ilerlemesi ile kondisyonsuzluğun fazlalaşması ve kaslarda (özellikle solunumla ilgili olanlarda) atrofinin ortaya çıkması daha da belirginleşebilir. Nefes darlığı, öksürük vd. semptomlar dinlenmede de günlük yaşamı giderek olumsuz etkilemeye başlar. Bir çok vakada geç kalınmış olarak tedaviye şikayetleri azaltmak ve/veya fiziksel gerileme sürecini yavaşlatmak için daha çok tempolu yürüme veya koşma gibi dayanıklılık egzersizleri, daha az olarak da ağırlık kaldırma vb. direnç egzersizleri eklenir ${ }^{10-12}$.

Genel olarak hastaların kondisyonlarını özel olarak solunum kaslarının güçlendirmek için önerilen çeşitli egzersiz programlarının çoğunlukla 30 dakika veya fazla sürdürülmesi istenir ${ }^{10}$. Ancak bir çok hastaya setler arasında 1-2 dakikalık nefeslenme dışında kesintisiz yaptırılan 30 dakika ve üzeri egzersizler uzun ve sıkıcı gelebilmekte, ayrıca ciddi kas ağrısı, aşırı yorgunluk gibi şikayetlere yol açabilmektedir ${ }^{11,12}$. Dolay1sıyla hastaların günlük antrenmanlarını erken sonlandırması veya programı tamamen birakmaları sonucu doğabilmektedir. $\mathrm{Bu}$ durumun önüne geçerek ileri dönemlerde özel rehabilitasyon programlarına ihtiyacı azaltmak veya olabildiğince geciktirmek için kişilerin özellikle ilk hastalık dönemlerinden itibaren (geç kalmadan) yapacakları ve kolay uyum sağlayacakları temel egzersiz programlarının geliştirilmesine gerek vardir.

Bu bağlamda, çalışmamızda hastaların alışkın oldukları ortamda, gün içinde bir kaç parçaya bölerek (her biri 5-10 dak süren, toplamda 20-25 dakikayı geçmeyen), hafif/orta şiddette alt veya üst ekstremite direnç egzersizlerini daha kolay yapabilecekleri öngörüsünde bulunduk. Alt veya üst ekstremiteler tercih edilerek olabildiğince az kas grubu kullanılması ile uyarılan metabolik stresin en aza indirilmesi ve egzersiz programına devamlılığının en üst düzeye çıkarılması amaçlandı. Literatürde uygulanan egzersizin tipine, süresine ve şiddetine bağlı olarak akciğer işlevlerine üst ekstremite egzersizlerinin daha faydalı olduğunu bildiren çalışmalar olduğu kadar, alt veya üst kas gruplarına ağırlık vermenin bir fark yaratmadığını ileri süren çalışmalar da vardır ${ }^{1-4,7,10-12}$. Bu yüzden, diğger birçok çalışmanın aksine erken dönemlerden itibaren, hafif kilolar ve basit aletler yardımı ile alt veya üst ekstremite gruplarına odaklanarak direnç egzersizine başlanmasının akciğer işlevleri üzerinde bir fark yaratıp yaratmadığını incelemek istedik. Aynı zamanda, alanda yaygın kullanılan, güvenilir bir anket olan St. George Solunum Anketi ile kişilerin hayat akışlarında yaptıkları bu değişsikliğin yaşam kalitelerini nasıl etkilediğini de gözlemlemeyi planladık.

\section{Gereç ve Yöntem}

Bir Devlet Üniversitesi Klinik Araştırmalar Etik Kurulu'ndan onam alındı (2017-13/55). Çalışma için, aynı Üniversite'nin Tıp Fakültesi Göğüs Hastalıkları Polikliniği'nde tedavi ve takibine devam edilen, 35-80 yaş arası, solunum fonksiyon testi uygulanabilen, ev egzersiz programına katılım sağlayabilecek 20 hafif/orta düzey akciğer hastası (dönem 1-2) ile akciğer sorunu bulunmayan, eşdeğer yaş grubunda 15 birey gönüllü oldu. Bu gruplar kendi içlerinde alt ve üst ekstremite direnç egzersizlerini yapmak üzere masa üzerinden rastgele çektirilen kapalı zarf yöntemi ile randomize olarak 2 alt gruba bölündü. Hastalardan alt ekstremite egzersizi yapacak 10 (AEH), üst ekstremite egzersizi yapacak 10 (ÜEH), kontrol için akciğer sorunu olmayanlardan alt ekstremite egzersizi yapacak 7 (AEK), üst ekstremite egzersizi yapacak 8 (ÜEK) kişiden oluşan toplam 4 grup oluşturuldu. Katılımcılar çalışma hakkında bilgilendirildi ve 'Bilgilendirilmiş Onam Formu' imzalatılarak fiziksel tanımlayıcı özellikleri ile ilgili veriler topland1.

Egzersiz programı: Günde 2 veya 3 parçaya bölerek, haftada 3 gün, 5'er tekrarla başlayan ev programı başlangıçta uygulamalı olarak katılımcılara gösterildi. Günlük antrenmanın her parçası kişiye göre 5-10 dakika arası ve toplamda 20-25 dakikalık süreyi geçmeyecek şekilde gerçekleşti. Şekil-1'de gösterilen egzersiz hareketleri; alt ekstremitelerde bacağa bağlanan kum torbalarını olabildiğince öne, arkaya, sağa ve sola yukarı kaldırma olarak belirlendi (bacak fleksiyon, ekstansiyon, abdüksiyon ve addüksiyonu). Üst ektsremitelerde su şişesini veya gerektiğinde serbest demir ağırlıkları öne, arkaya, sağa ve sola yukarıya (kol fleksiyon, ekstansiyon, abdüksiyon ve addüksiyonu) kaldırma olarak belirlendi. Egzersizin başlangıç şiddeti hafif/orta düzeyde olacak şekilde katılımcıların kaldırabildikleri 1 maksimum tekrarın \%30 ağırlığına göre saptand ${ }^{13}$. Katılımc1larla belirli dönemlerde 


\section{Direnç Egzersizinin Akciğer İşlevleri ve Yaşam Kalitesine Etkisi}
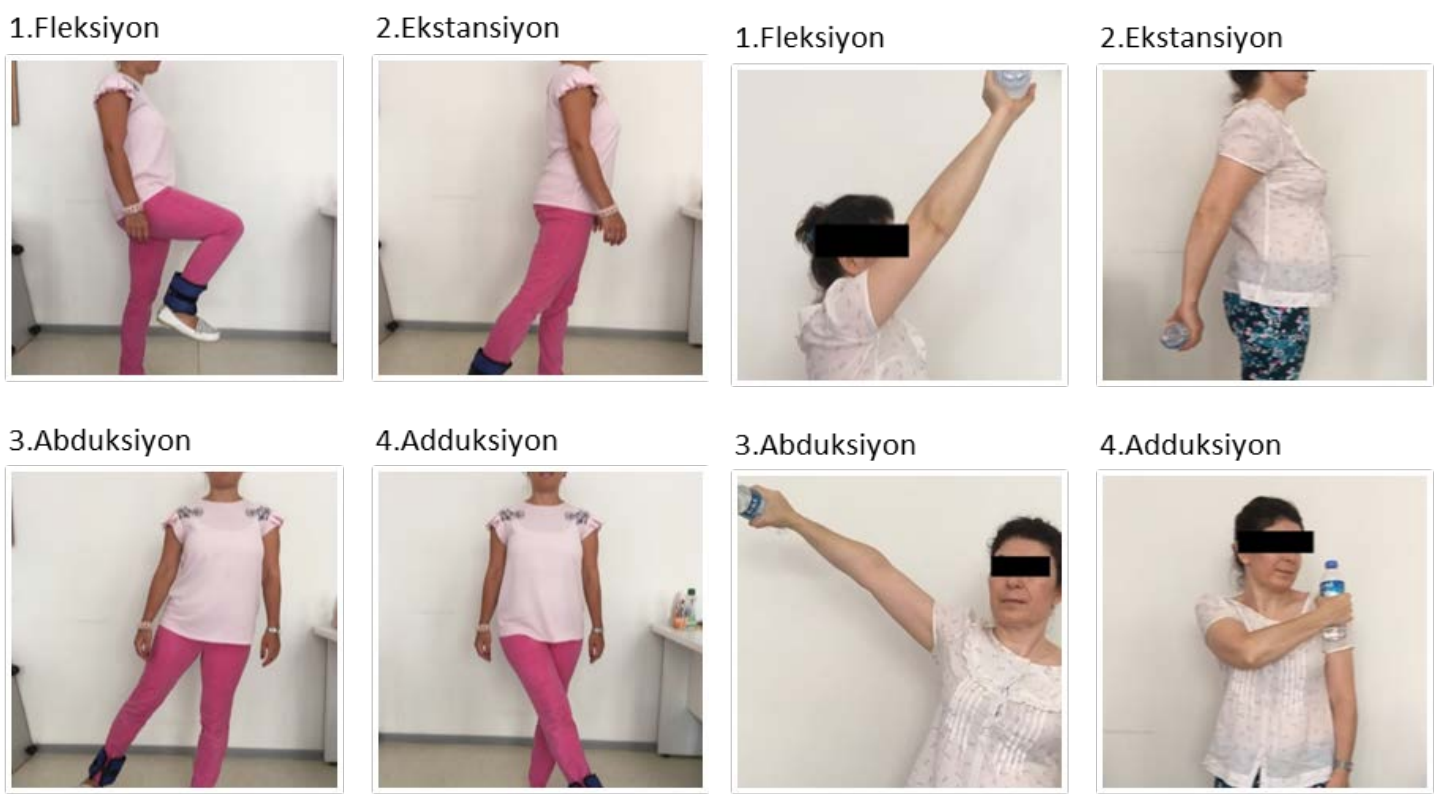

Şekil 1:

Alt ve üst ekstremite direnç egzersizleri.

iletişime geçilerek ev programının gerçekleştirilmesi ve devamlılık izlendi. İlerleyen haftalarda ağırlık ve tekrar sayısını arttırmaları teşvik edildi. En az 2 en fazla 4 ay devam eden antrenman programı sonunda, kontrol grubu katılımciların tamaminda $(\% 100)$, hasta grubu katılımcıların 9'unda (\%45) kaldırdıkları ağırlık miktarında \% 20-50 oranında artış saptandı. Hastalar program boyunca rutin tedavilerine devam etti. Tedavisi değiştirilen hastalar ise çalışma dışı bırakıldı.

Solunum Fonksiyon testleri: Üniversitenin Tıp Fakültesi Göğüs Hastalıkları AD Solunum Laboratuvarı biriminde egzersiz programı öncesi ve 2-4 ay sonrasinda katılımciların $\mathrm{FEV}_{1}, \mathrm{FVC}, \mathrm{FEV}_{1} / \mathrm{FVC}, \mathrm{PEF}$, $\mathrm{MEF}_{75}, \mathrm{MEF}_{50}, \mathrm{MEF}_{25}$ ölçümleri (ZAN®Spirometre, ABD ile) uluslararası standartlara göre yapıld $1^{14}$.

Yaşam kalitesi ölçümü: Hasta grubuna egzersiz programı öncesi ve 2-4 ay sonrasında, 50 maddeden oluşan ve 3 alt boyutu (semptom-8 soru, etki-26 soru, aktivite-16 soru) olan St. George Solunum Anketi (St. George's Respiratory Questionnaire, SGRQ) uygulan$\mathrm{d}^{15}{ }^{15}$. SGRQ, Türkçe geçerlilik ve güvenilirliği test edilmiş solunum hastalıkları için kapsamlı bir yaşam kalitesi anketidir ${ }^{16}$. Semptom alt boyutunda semptomların sıklık ve şiddetini ölçen, etki alt boyutunda hava yolu hastalığından kaynaklanan sosyal fonksiyon yetersizliği ve psikolojik sorunları değerlendiren, aktivite alt boyutunda nefes darlığına yol açan ve solunumu kisitlayan aktiviteleri sorgulayan sorular mevcuttur. Her soruda hastanın verdiği cevaba göre ' 1 ' veya ' 0 ' puan verilir. $\mathrm{Bu}$ anketin toplam puan skoru 0-100 arasında değişmektedir. Skor 0’a ne kadar yakınsa sağlığın o kadar iyi, 100'e ne kadar yakınsa o kadar kötü olduğuna işaret etmektedir.

\section{İstatistiksel Analiz}

İstatistiksel analiz için bilgisayar ortamında SPSS 20.0 programı (SPSS Inc., Chicago, IL, ABD) kullanıldı. Verilerin normal dağılıma uygunluğu Shapiro Wilk testiyle belirlendi. Parametrik veriler için sonuçlar 'ortalama \pm standart sapma' şeklinde verildi. Ortalamalar arasındaki farkların hesaplanması t-testi ile yapıldı. Parametrik olmayan veriler için MannWhitney $U$ ve Kruskal-Wallis testleri kullanılarak sonuçlar 'medyan (minimum-maksimum)' şeklinde verildi. Tukey testiyle değerler arasındaki ilişkiler hesaplandı. Anlamlılık düzeyi $\mathrm{p}<0,05$ olarak kabul edildi.

\section{Bulgular}

Çalışmaya kabul edilen hasta grubu katılımcılar 35-80 yaş aralığındadır. Alt ekstremite egzersizi yapan hasta $(\mathrm{AEH})$, üst ekstremite egzersizi yapan hasta (ÜEH), alt ekstremite egzersizi yapan kontrol (AEK), üst ekstremite egzersizi yapan kontrol (ÜEK) grubu kat1lımcıların fiziksel özellikleri (yaş, boy, kilo, VKİ) Tablo I'de gösterilmiştir.

Gerek hasta gerekse kontrol grubundaki katılımcıların egzersiz programı sonrasinda solunum fonksiyon testi (SFT) parametrelerinde $\left(\mathrm{FEV}_{1}, \mathrm{FVC}, \mathrm{FEV}_{1} / \mathrm{FVC}, \mathrm{PEF}\right.$, $\mathrm{MEF}_{75}, \mathrm{MEF}_{50}, \mathrm{MEF}_{25}$ ) egzersiz programı öncesi değerlere göre anlamlı düzeyde bir farklılık saptanmamıştır ( $p>0,05)$ (Tablo II). 
Tablo I. Katılımcıların fiziksel özellikleri.

\begin{tabular}{|c|c|c|c|c|}
\hline & AEH (n=10) & ÜEH (n=10) & AEK $(n=7)$ & ÜEK (n=8) \\
\hline Yaş (yıl) & $50 \pm 8$ & $53 \pm 9$ & $49 \pm 10$ & $44 \pm 9$ \\
\hline Boy (cm) & $164 \pm 8$ & $163 \pm 6$ & $159 \pm 8$ & $166 \pm 7$ \\
\hline Kilo $(\mathrm{kg})$ & $78 \pm 19$ & $75 \pm 13$ & $65 \pm 10$ & $73 \pm 12$ \\
\hline VKi $\left(\mathrm{kg} / \mathrm{m}^{2}\right)$ & $28 \pm 7$ & $28 \pm 4$ & $25 \pm 2$ & $26 \pm 2$ \\
\hline
\end{tabular}

Bulgular; Medyanıstandart sapma olarak gösterilmiștir. AEH; Alt Ekstremite egzersizi yapan Hasta grubu, ÜEH; Üst Ekstremite egzersizi yapan Hasta grubu, AEK; Alt Ekstremite egzersizi yapan Kontrol grubu, ÜEK; Üst Ekstremite egzersizi yapan Kontrol grubu, VKİ; Vücut kitle indeksi.

Tablo II. Katılımcıların egzersiz öncesi ve sonrası SFT karşılaştırması.

\begin{tabular}{|c|c|c|c|c|}
\hline \multirow{2}{*}{$\begin{array}{c}\text { SFT } \\
\text { Parametresi }\end{array}$} & \multicolumn{4}{|c|}{$\begin{array}{l}\text { Egzersiz Öncesi (EÖ) ve Egzersiz Sonrası (ES) } \\
\text { değerleri [medyan(minimum-maksimum)] }\end{array}$} \\
\hline & & EÖ & ES & $\mathrm{p}$ \\
\hline \multirow{4}{*}{ FVC } & AEH & $3,47(2-4)$ & $3,45(2-4)$ & \multirow{4}{*}{$>0,70$} \\
\hline & ÜEH & $3,43(2-4)$ & $3,42(2-4)$ & \\
\hline & AEK & $3,18(2-4)$ & $3,16(2-4)$ & \\
\hline & ÜEK & $3,50(1-5)$ & $3,48(1-5)$ & \\
\hline \multirow{4}{*}{$\mathrm{FEV}_{1}$} & AEH & $2,88(2-3)$ & $2,82(2-3)$ & \multirow{4}{*}{$>0,59$} \\
\hline & ÜEH & $2,79(2-3)$ & $2,78(2-3)$ & \\
\hline & AEK & $2,63(2-3)$ & $2,62(2-3)$ & \\
\hline & ÜEK & $2,92(1-4)$ & $2,93(1-4)$ & \\
\hline \multirow{4}{*}{$\mathrm{FEV}_{1} / \mathrm{FVC}$} & AEH & $79,40(76-83)$ & $79,20(76-82)$ & \multirow{4}{*}{$>0,28$} \\
\hline & ÜEH & $77,70(75-81)$ & $77,70(75-81)$ & \\
\hline & AEK & $78,85(73-82)$ & $78,71(74-81)$ & \\
\hline & ÜEK & $79,62(76-82)$ & $79,75(75-82)$ & \\
\hline \multirow{4}{*}{ PEF } & AEH & $7,16(6-8)$ & $7,13(6-8)$ & \multirow{4}{*}{$>0,75$} \\
\hline & ÜEH & $7,31(5-8)$ & $7,29(5-8)$ & \\
\hline & AEK & $6,82(5-8)$ & $6,79(5-8)$ & \\
\hline & ÜEK & $7,19(4-9)$ & $7,19(4-9)$ & \\
\hline \multirow{4}{*}{$\mathrm{MEF}_{75}$} & AEH & $6,29(5-7)$ & $6,29(5-7)$ & \multirow{4}{*}{$>0,79$} \\
\hline & ÜEH & $6,47(5-7)$ & $6,46(5-7)$ & \\
\hline & AEK & $6,08(5-7)$ & $6,07(5-7)$ & \\
\hline & ÜEK & $6,37(4-8)$ & $6,38(4-8)$ & \\
\hline \multirow{4}{*}{$\mathrm{MEF}_{50}$} & AEH & $4,14(3-4)$ & $6,20(5-7)$ & \multirow{4}{*}{$>0,05$} \\
\hline & ÜEH & $4,04(3-4)$ & $6,40(5-6)$ & \\
\hline & AEK & $3,96(3-4)$ & $3,95(3-4)$ & \\
\hline & ÜEK & $4,21(2-5)$ & $4,22(2-5)$ & \\
\hline \multirow{4}{*}{$\mathrm{MEF}_{25}$} & AEH & $1,70(1-2)$ & $1,96(1-3)$ & \multirow{4}{*}{$>0,31$} \\
\hline & ÜEH & $1,51(1-2)$ & $1,50(1-2)$ & \\
\hline & AEK & $1,56(0-2)$ & $1,61(1-2)$ & \\
\hline & ÜEK & $1,73(0-2)$ & $1,78(0-2)$ & \\
\hline
\end{tabular}

Bulgular; Medyan (minimum-maksimum) olarak gösterilmektedir. AEH(n=10); Alt Ekstremite egzersizi yapan Hasta grubu, ÜEH(n=10); Üst Ekstremite egzersizi yapan Hasta grubu, AEK(n=7); Alt Ekstremite egzersizi yapan Kontrol grubu, ÜEK(n=8); Üst Ekstremite egzersizi yapan Kontrol grubu. FVC; Zorlu Vital Kapasite, $\mathrm{FEV}_{1}$; Zorlu Ekspiratuvar Volümun 1.saniyesi, PEF; Pik Ekspiratuvar Akım, $\mathrm{MEF}_{75,50,25}$; Maksimum Ekspiratuvar Akımın $\% 75,50$ ve 25 'i.

Alt ve üst ekstremite egzersizleri yapıldığında akciğer işlevleri açısından SFT parametrelerine yansıyan anlamlı bir değişikliğin oluşmadığı da yapılan analizler sonucu anlaşılmıştır. Hem AEH ile ÜEH grupları hem de AEK ile ÜEK grupları arasında, egzersiz programı sonrasında SFT parametreleri açısından anlamlı düzeyde bir fark görülmemiştir ( $\mathrm{p}>0,05)$ (Tablo III).
Tablo III. Alt veya üst ekstremite egzersizinin solunum fonksiyonlarına etkisi.

\begin{tabular}{|c|c|c|c|c|c|c|c|}
\hline$p$ & $F V C$ & FEV $_{1}$ & FEV $_{1} / F V C$ & PEF & MEF $_{75}$ & MEF $_{50}$ & $M^{\prime} F_{25}$ \\
\hline AEH-ÜEH & 0,82 & 0,59 & 0,14 & 0,91 & 0,82 & 0,82 & 0,05 \\
\hline AEK-ÜEK & 0,38 & 0,29 & 0,23 & 0,48 & 0,56 & 0,24 & 0,56 \\
\hline
\end{tabular}

AEH(n=10); Alt ekstremite egzersizi yapan hasta grubu, ÜEH(n=10); Üst ekstremite egzersizi yapan hasta grubu, AEK(n=7); Alt Ekstremite egzersizi yapan Kontrol grubu, ÜEK(n=8); Üst Ekstremite egzersizi yapan Kontrol grubu. FVC; Zorlu Vital Kapasite, $\mathrm{FEV}_{1}$; Zorlu Ekspiratuvar Volümun 1.saniyesi, PEF; Pik Ekspiratuvar Akım, MEF $_{75,50,25}$; Maksimum Ekspiratuvar Akımın \%75, 50 ve 25'i.

Tablo II ve Tablo III'teki veriler bir arada incelendiğinde katılımcıların yaptığı alt veya üst ekstremite egzersizleri arasında (en azından bu antrenman süresi ve bu egzersiz şiddeti kapsamında) solunum işlevlerinde beklenen gelişmenin oluşması açısından bir fark saptanamamıştır.

Diğer taraftan AEH ve ÜEH gruplarında yaşam kalitesinin değerlendirilmesinde ise bireylerin egzersiz sonrası St. George's Solunum Anketi puanları hem alt boyutlarda hem de toplam puan olarak egzersiz öncesine göre anlamlı düzeyde azalma göstermiştir $(\mathrm{p}<0,001)$ (Tablo IV).

Tablo IV. Hasta grubu St. George Solunum Anketi (SGRQ) puan karşılaştırması.

\begin{tabular}{|c|c|c|c|c|}
\hline \multirow{2}{*}{$\begin{array}{c}\text { SGRQ } \\
\text { bileşenleri }\end{array}$} & \multicolumn{4}{|c|}{$\begin{array}{c}\text { Egzersiz Öncesi (EÖ) ve Egzersiz Sonrası } \\
\text { (ES) değerleri } \\
\text { (Ort. } \pm \text { Std.Sapma) }\end{array}$} \\
\cline { 2 - 5 } & & EÖ & ES & $p$ \\
\hline \multirow{2}{*}{ Semptom } & AEH & $6,90 \pm 0,73$ & $3,40 \pm 0,69$ & $<0,001^{*}$ \\
& ÜEH & $6,80 \pm 0,78$ & $3,00 \pm 0,66$ & \\
\hline \multirow{2}{*}{ Aktivite } & AEH & $25,00 \pm 0,81$ & $11,50 \pm 0,52$ & $<0,001^{*}$ \\
& ÜEH & $24,70 \pm 0,94$ & $11,80 \pm 1,13$ & \\
\hline \multirow{2}{*}{ Etki } & AEH & $14,90 \pm 0,87$ & $7,20 \pm 0,63$ & $<0,001^{*}$ \\
& ÜEH & $14,40 \pm 1,34$ & $6,80 \pm 0,78$ & \\
\hline \multirow{2}{*}{ Toplam } & AEH & $46,80 \pm 1,54$ & $21,10 \pm 0,87$ & $<0,001^{*}$ \\
& ÜEH & $45,90 \pm 1,44$ & $21,60 \pm 0,84$ & $<0,81$, \\
\hline
\end{tabular}

Bulgular; Medyan \pm standart sapma olarak gösterilmiştir. Ort; Ortalama, Std; Standart, AEH (n=10); Alt Ekstremite egzersizi yapan Hasta grubu, ÜEH $(n=10)$; Üst Alt Ekstremite egzersizi yapan Hasta grubu, AEK; Alt Ekstremite egzersizi yapan Kontrol grubu, ÜEK; Üst Ekstremite egzersizi yapan Kontrol grubu, SGRQ; St. George's Respiratory Questionnaire, ${ }^{*} \mathrm{p}<0,05$.

\section{Tartışma ve Sonuç}

Pulmoner hastalıklar, mortalite ve morbidite nedeniyle çok önemlidir. Egzersiz intoleransı da solunum yolu hastalıklarının en önemli sonuçlarından birisidir. $\mathrm{KOAH}$, kronik akciğer hastalıkları içinde en yaygın olanıdır ve başlıca solunum sistemi ile ilişkili ölümle- 


\section{Direnç Egzersizinin Akciğer İşlevleri ve Yaşam Kalitesine Etkisi}

rin, aktivite ve katılım k1sıtlanmalarının nedeni$\operatorname{dir}^{5,11,17,18}$. Hastalığın hafif evrelerinde, hastalarda ağır egzersiz sırasında dispne oluşabilir. Orta ve ileri dönem solunum hastaları ise normal günlük işleri yaparken bile sıkıntı yaşayabilirler. Egzersiz sırasında ise dispne ve bacak yorgunluğu hareketleri kısitlayan temel semptomlardır ${ }^{5,10,17}$. Amerikan Toraks Derneği, solunum hastalarının \% 51 'inde iş kapasitesinde yetersizliğin, \% 70’inde normal fiziksel egzersizin, \% 56'sında ev işlerinin, \% 53'ünde sosyal aktivitelerin, \% 50'sinde uykunun ve \% 46'sinda aile ile gerçekleştirilen aktivitelerinin kısıtlandığını rapor etmiş$\operatorname{tir}^{18}$. Solunum hastalarında oluşan ataklar nefes darlığ 1 , hışıltılı solunum, göğüste sıkışma hissi ve öksürük gibi semptomlar ile karakteristiktir ${ }^{19}$. Solunum hastalarının sağlık durumu ve yaşam kalitesi arasındaki ilişkinin araştırıldığ 1 bir çalışmada, hastalardaki aktivite kısıtlanmasının yaşam kalitesinin en önemli belirleyicisi olduğunu bildirilmiştir ${ }^{20}$. Bourbeau ve arkadaşlarının gerçekleştirdikleri 421 solunum hastasını kapsayan 6 ay takipli çalışmada hastalık atağının erken tanınmasını takiben hastaların \% 71'inde SGRQ etki skorunda önemli ölçüde bozulma olduğu gösterilmiş$\operatorname{tir}^{21}$. Coronell ve arkadaşları, hafif-orta şiddetli KOAH'l1larda ve normal fiziksel aktivite seviyesindeki hastalarda bile, kuadriseps kas enduransının sağlıklı kontrol olgularından daha düşük olduğunu ve bunun kas zayıflığı veya hastalık şiddetinden daha çok kas yorgunluğunun erken başlamasıyla ilişkili olduğunu göstermişlerdir ${ }^{22}$. KOAH'ta üst ekstremite kas enduransı ile ilgili sınırlı sayıda yapılan çalışmalarda biseps kası dayanıklılığının sağlıklı bireylerden \% 10 daha düşük olduğu bildirilmiştir ${ }^{23}$. Bensten ve arkadaşlarının çalışmalarında KOAH'lı hasta grubunda egzersiz sonrasında görülen ağrı şikayetinin oranı (\%45), kontrol grubunda görülen ağrı şikayetinin oranına (\%34) göre anlamlı düzeyde yüksek olduğu bulunmuştur ${ }^{24}$.

Ayrıca yukarıdaki anılan ve benzer bir dizi çalışmada; katılımcı bireylerden bazılarının, uzun süreli (özellikle $\geq 25$-30 dakika) ve yeterli dinlenme arası verilmeyen antrenmanları bir külfet olarak algıladıkları, yardımcı tedavi olarak kabul etmede, katılım ve devamlılık sağlamada isteksiz oldukları bildirilmiştir ${ }^{10,18,20-25} . \mathrm{Bu}$ durumu göz önüne alarak düzenlenen çalışmamızda bireylere günlük yaşamları sırasında özellikle parçalara bölerek antrenman yaptırılmıştır. Gün içerisinde egzersiz hareketlerinin bir k1smının sabah, diğer k1sımların öğleden sonrası ve/veya akşam saatlerinde yapılması tüm antrenmandan sıkılmayı veya yarıda bırakmayı en aza indirmiş, hareketlerin tamamlanması açısından devamlılık sağlamıştır. Ancak katılımcıların egzersiz programı sonrası SFT parametrelerinde egzersiz öncesine göre istatistiksel olarak anlamlı bir fark bulunamamıştır. Bu noktada antrenman süresinin 4-6 ay veya daha fazla olması, haftalar içinde ağırlık ve tekrar sayısının biraz daha cesurca yükseltilmesinin bir fark yaratabileceği düşünülebilir. Nitekim daha üst seviyedeki egzersiz şiddeti ile yapılan çalışmalarda hastaların solunum işlevi parametrelerinde 1lımlı gelişmelerin saptanmasının yanı sıra günlük işlerini yapmada rahatlama bildirilmiştir ${ }^{12,26,27}$.

Diğer taraftan, yapılan bazı çalışmalarda, bizim araştırmamızda olduğu gibi hastaların SFT parametreleri üzerine önemli bir farklılık olmasa da yaşam kalitesinde belirgin düzelmeler saptanmıştır ${ }^{26,28}$. Çalışmamızda SGRQ yaşam kalitesi anketi ile egzersiz programı sonrasında hasta grubunun skorları anlamlı düzeyde azalmıştır. Toplam skorda 4 birimlik değişism anlamlı kabul edilmektedir. Bizim çalışmamızda toplam skorda her iki ekstremite egzersiz grubunda da 20 puan üstü bir değişme görülmüş (Tablo IV) ve hastalarımızın yaşam kalitesinde önemli bir iyileşme elde edilmiştir. Nispeten hafif/orta yoğunluktaki bir egzersiz programı bile hastalık semptomlarının şiddet ve sıklığında azalma, hastaların günlük yaşam aktivitelerinde nispeten rahatlama, hastalığın oluşturduğu psikolojik durumda iyileşme sağlamıştır. Daha yüksek yoğunlukta ve bölünmeden yapılan egzersizlerle benzer sonuçlar bildiren bazı çalışmalar da vardır ${ }^{25-27}$. Ayrıca çalışmamızda; parçalara bölünmesi dolayısıyla daha az metabolik/psikolojik stres yüklemesi oluştuğundan, devamlılık \%95 gibi yüksek bir oranda seyretmiştir. Anılan noktalar göz önüne alındığında, çalışmamız gün içinde parçalara bölünerek yapılan hafif/orta şiddetteki egzersizlerin de hastalara faydalı olabileceğini gösteren bir öncü araştırma vasfindadır.

Çalışmamızın kısıtları hasta ve kontrol gruplarında dinamometre $v b$. yöntemler yardımı ile kas gücündeki gelişmeyi ölçme imkânımızın olmayışıdır. Her iki grupta da gönüllü sayılarının biraz daha fazla olması ve daha uzun bir takip süresi, yine zaman kısıtlılı̆̆ dolayısıyla mümkün olamamıştır. Diğer yandan VKI 30 üzeri olan kişilerde egzersizin daha kısa sürede ve daha belirgin etki göstermesi beklenir, ancak bu özellikteki hastalar çalışmamızda gönüllü olmaya çok daha az istekli olmuşlardır.

Sonuç olarak, kronik akciğer sorunu olan hastaların hafif/orta şiddette alt veya üst ekstremite direnç egzersizlerini parçalara bölerek 2-3 kerede tamamlasalar bile ev ortamında düzenli yaparak yaşam kalitelerini yükseltebilecekleri görülmüştür. Yaşam kalitelerindeki bu belirgin ilerlemenin SFT sonuçlarına da somut olarak yansıması için 2-4 aydan biraz daha uzun antrenman süresi gerektiği düşünülebilir. Ayrıca programdaki egzersizlerin başlangıçtan itibaren şiddetinin daha iyi belirlenmesi, yüklemelerin daha doğru ayarlanması ve hareketlerin tam gerçekleştirilme derecesinin daha yakından izlenmesi de yararlı olabilir. Bu noktalar göz önüne alındığında bu tür egzersiz programlarında, katılımcıların egzersiz ve hastalık ilişkisi bakımından daha fazla bilinçlendirilmeleri ihtiyacı belirgin hale gelmiştir. İlaveten, ev egzersiz programlarının umulan faydayı gösterme olasılığını daha da yükseltmek için hastanın bir yakınının da yeterli bi- 


\section{H.O. Ünal, ark.}

linçlendirme yapılarak tedavi programı destek ekibi içine alınması önerilebilir.

\section{Kaynaklar}

1. Lopez AD, Shibuya K, Rao C et al. Chronic obstructive pulmonary disease current burden and future projections. European Respiratory Journal. 2006; 27(2): 397-412.

2. Yılmaz A, Erkan F. Astımda Maliyet Etkinlik Analizleri. Toraks Dergisi. 2002; 3(1):70-74.

3. Global Initiative for Chronic Obstructive Lung (GOLD) 2017 Erişim adresi: http://www.goldcopd.com. Erișim tarihi: 20.04.2019.

4. Chacon PFS, Schon CF, Furtado VHLA et al. Support and rehabilitation of patients with pulmonary expansion deficit by using game therapy. Annu Int.Conf. 2016; 5632-5.

5. T.C. Sağlık Bakanlığı Temel Sağlık Bilgi Sistemleri Genel Müdürlüğü. Türkiye Kronik Hava Yolu Hastalıkları Önleme ve Kontrol Programı (2014 - 2017) Eylem Planı, Ankara, 2014; 947: 4-31.

6. Fontana L, Lee SJ, Capitanelli I et al. Chronic Obstructive Pulmonary Disease in Farmers: A Systematic Review. J Occup Environ Med. 2017; 59(8):775-88.

7. Sadhra S, Kurmi OP, Sadhra SS et al. Occupational COPD and job exposure matrices: a systematic review and meta-analysis. Int J Chron Obstruct Pulmon Dis. 2017; 12:725-34.

8. Pauwels RA, Rabe KF. Burden and clinical features of chronic obstructive pulmonary disease (COPD). Lancet. 2004; 364: 613-620.

9. Eapen MS, Myers S, Walters EH et al. Airway inflammation in chronic obstructive pulmonary disease (COPD). Expert Rev Respir Med. 2017; 1-13.

10. British Thoracic Society Standarts of Care Subcommittee on Pulmonary Rehabilitation. Pulmonary Rehabilitation. Thorax. 2001; 56: 827-83.

11. Ries AL, Bauldoff GS, Carlin BW et al. Pulmonary Rehabilitation: Joint ACCP/AACVPR Evidence-Based Clinical Practice Guidelines. Chest. 2007; 131(5): 4-42.

12. Pedersen BK, Saltin B. Exercise as medicine-evidence for prescribing exercise as therapy in 26 different chronic diseases. Scandinavian Journal of Medicine \& Science in Sports. 2015; 25(3): 1-72

13. Kraemer WJ, Ratamess NA. Fundamentals of resistance training: progression and exercise prescription. Medicine\&Science in Sports\&Exercise. 2004; 36 (4):674-688.
14. Miller MR, Hankinson J, Brusasco V, et al. ATS/ERS Task Force. Standardisation of spirometry. European Respiratory Journal. 2005; 26(2): 319-338.

15. Jones PW, Quirk FH, Baveystock CM. The St. George's Respiratory Questionnaire. Respiratory Medicine. 1991; 85: 25-31.

16. Mehmet P, Arzu Y, Ömer A ve ark. St. George solunum anketinin Türkçe geçerlilik ve güvenilirliği. Tüberküloz ve Toraks. 2013; 61(2): 81-87.

17. Kocabas A, Hancioğlu A, Türkyılmaz $\mathrm{S}$ et al. Prevalence of chronic obstructive pulmonary disease in Adana. Proceedings of the American Thoracic Society. 2006; 3: 543.

18. American Lung Association. Lung Disease Data. 2008; 27-54.

19. Erk M. Göğüs Hastalıkları II.Cilt, İstanbul Üniversitesi Yayınları, İstanbul: 2001; 62 -659.

20. Jones PW. Activity limitation and quality of life in COPD. COPD: Journal of Chronic Obstructive Pulmonary Diseases. 2007; (4):273- 8.

21. Bourbeau J. Impact on patients' health status following early identification of a COPD exacerbation. European Respiratory Journal. 2007; 30- 907.

22. Coronell C, Orozco-Levi M, Mendez R et al. Relevance of assessing quadriceps endurance in patients with COPD. European Respiratory Journal. 2004; 24: 129- 136.

23. Fritz M, Fransen E, Broekhuizen R et al. Limp muscle dysfunction in COPD: Effects of muscle wasting and exercise trainig. Medicine \& Science in Sports \& Exercise. 2005; 37: 2-9.

24. Bentsen S, Christine M, Bruce AC et al. Distinct pain profiles in patients with chronic obstructive pulmonary disease. Int $\mathrm{J}$ COPD. 2018; 13:801-811.

25. Mancuso C, Sayles W, Robbins L, Phillips E. Barriers and facilitators to healthy physical activity in asthma patients. Journal of Asthma. 2006; 43(2):137-143.

26. Pan L, Guo YZ, Yan JH et al. Does upper extremity exercise improve dyspnea in patients with COPD? A meta-analysis. Respiratory Medicine. 2012; 106: 1517-1525

27. Strasser B, Siebert U, Schobersberger W. Effects of resistance training on respiratory function in patients with chronic obstructive pulmonary disease:a systematic review and metaanalysis. Sleep and Breathing. 2013; 17: 217-226

28. Demoly P, Gueron B, Annunziata K, Adamek L, Walters RD. Update on asthma control in five European countries results of a 2008 survey. European Respiratory Journal. 2010; 19(16):150-157. 